\title{
Separated Microphase Structure and Mechanical Properties of Blood-compatible Polyurethaneureas
}

\author{
Yuko IkedA ${ }^{* 1}$, Shinzo KoHjIYA*1, Shinzo Yamashita*1, \\ Hisao HAYASHI ${ }^{* 2}$, and Tatsuya OKUnO*3 \\ *1Department of Chemistry, Kyoto Institute of Technology, \\ Matsugasaki, Kyoto 606, Japan \\ *2Department of Polymer Chemisty, Kyoto University, \\ Yoshida, Kyoto 606, Japan \\ *3Sunstar Engineering Inc., Kamihamuro, Takatsuki 569, Japan
}

\begin{abstract}
ABA type triblock copolymer, poly (oxyethylene)-poly (oxytetramethylene)-poly(oxyethylene) (PEO-PTHF-PEO) was used as prepolymer for preparing segmented polyurethaneureas (SEUU). The introduction of hydrophilic PEO segments was very effective for improving both the blood-compatibility and the mechanical properties of segmented polyurethaneureas. The best antithrombogenisity was attained by SEUU of $33 \mathrm{~mol} \%$-EO-content. In addition to a better antithrombogenicity, SEUU displayed excellent mechanical properties, lower modulus and higher elongation, as well as a high tensile strength as compared with polyurethaneurea (SPUU) without PEO segments. These mechanical characteristics are similar to those of a living soft tissue. The morphology of segmented polyurethaneureas was investigated by DSC, SAXS and dynamic mechanical measurements. The microphase separation was observed in all polymers. However, segmented polyurethaneureas having PEO segments showed phase separation more clearly than SPUU. The improvements in properties of SEUU might be attributed to better microphase separation than SPUU. Key words: Polyuretaneurea / Mechanical Properties / Blood Compatibility / Microphase Structure
\end{abstract}

\section{血液適合性セグメント化ポリウレタンゥレア のミクロ相分離構造と力学的性質}

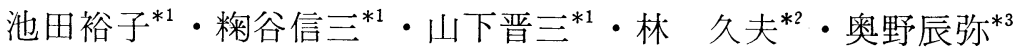

（原稿受理：1989年 5 月 1 日）

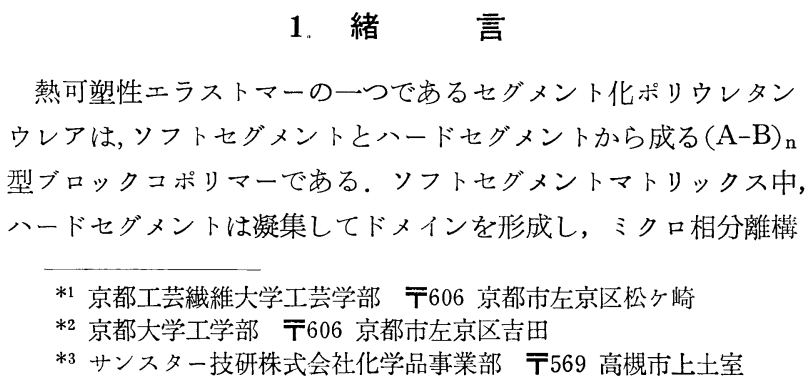

造を示すことが知られている。ソフトセグメントマトリックスは 室温でゴム状態にあり，ハードセグメントドメインは架橋点の役 割を果たし良好なゴム弾性体，すなわらエラストマーとなる。

一般にソフトセグメント成分としては, 分子量600～3, 000程度 のポリエーテルやポリエステルが用いられ, ジイソシアナートと ジオールあるいはジアミンによりハードセグメントが形成される。 ポリ（オキシテトラメチレン（PTHF）やポリ（オキシプロピレ ン) (PPO), ポリ(オキシェチレン) (PEO) などのポリエーテル を用いたセグメント化ポリウレタンウレアの研究は盛んで，特に 
Boretosら ${ }^{1), 2)}$ によって抗血栓性に優れていると報告されて以来， 人工心臓や人工血管など血液と接触して用いられる医用材料とし

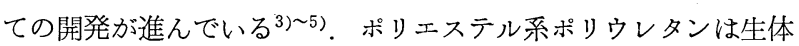
内分解性を有して拈り，体内吸収性の人工血管や縫合系などへの 応用が考えられている6).

著者らは PEO-PTHF-PEO トリブロックコポリエーテルをソ フトセグメントとするセグメント化ポリウレタンウレア(SEUU) が優れた血液適合性と機械的性質を示し，人工血管などの素材と

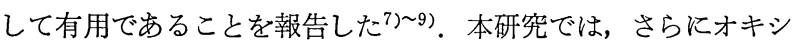
エチレン(EO)含量 $62 \mathrm{~mol} \%$ のリブロックコポリマーより合成 されたセグメント化ポリウレタンウレアを追加し, 力学的性質を 中心とした特性を評価し, 抗血栓性や力学的性質をミクロ相分離 構造と関連させて議論する。

\section{2. 実 験}

$2 \cdot 1$ セグメント化ポリウレタンウレアの合成

SEUU (Fig. 1) は1,8-ジアザビシクロ[5.4.0] ウンデセン-7

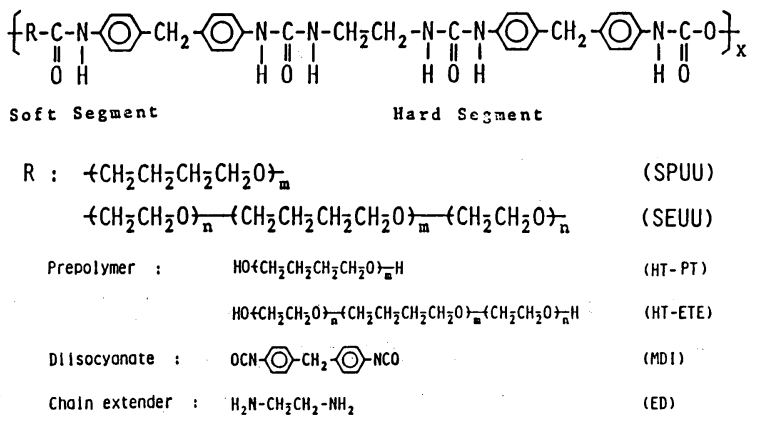

Fig. 1 Chemical structures of segmented polyurethaneureas and their raw materials.

(DBU) を触媒として，N， N'-ジメチルアセトアミド (DMAc) 中プレポリマー法により合成した7)。プレポリマーにはアニオン 重合法により合成した水酸基末端 PEO-PTHF-PEO トルブロッ クコポリマー (HT-ETE, Fig. 1) を用いた. ジイソシアナート は 4, 4'-ジフェニルメタンジイソシアナート (MDI) を, 鎖延長剤 はエチレンジアミン (ED) を用い, 仕込みモル比はプレポリマー $/ \mathrm{MDI} / \mathrm{ED}=1 / 2 / 1$ である。 得られたポリウレタンウレアはソッ
クスレー抽出（抽出溶媒，アセトン；48時間）を行って精製し， $40^{\circ} \mathrm{C}$ で減圧乾燥した。市販の三洋化成工業(侏製水酸基末端 $\mathrm{PTH}$ F (HT-PT, 分子量1830) を用いて同様に合成されたセグメント 化ポリウレタンウレアをSPUU と略称する.

\section{$2 \cdot 2$ セグメント化ポリウレタンウレアフィルムの作製}

物性試験に供したフィルムは, SEUUあるいはSPUU の $10 \mathrm{wt}$ \% DMAc 溶液よりキャスト法で成膜した。溶媒の蒸発は減圧下

(5 mmHg 以下), 室温から $50^{\circ} \mathrm{C}$ まで加熱して行った.

$2 \cdot 3$ セグメント化ポリウレタンウレアの抗血栓性

in vitro 試験として Lee-White 法凝血試験 7 ,10) を行った。年 齢の異なる数人の男性の血液を用い, 各試料について 5 回以上測 定してガラス表面の凝血時間を 1.0 とする相対值，すなわち，凝 血時間指標 (CTI) により抗血栓性を評価した。

$2 \cdot 4$ セグメント化ポリウレタンウレアの示差走査型熱量計 (DSC) 測定

フィルム状試料を用いて, 理学電機㑣)製 DSC-8230 型を用い, 开温速度 $10^{\circ} \mathrm{C} / \mathrm{min}$ で測定した.

$2 \cdot 5$ セグメント化ポリウレタンウレアの小角 X 線散乱 (SAX S) 測定

フィルム状試料を用いて, 京都大学超強力 $\mathrm{X}$ 線回折実験室のシ グマ光機(㑣)製点収束型小角X線散乱装置 ${ }^{11}$ )より測定した。検出 器は 2 次元位置敏感型比例計数管を, X線源としては $\mathrm{CuK}_{\alpha}$ 線を, フィルターは Niフィルターを使用した。

\section{$2 \cdot 6$ セグメント化ポリウレタンウレアの引張試験}

引張試験は新興通信工業(㑣)製 TOM 200D 型引張試験機を用い て行った. 厚さ約 $350 \mu \mathrm{m}$, 幅 $5 \mathrm{~mm}$, 長さ $4 \sim 5 \mathrm{~cm}$ のたんざく状つ イルムと, $37^{\circ} \mathrm{C}$ 生理食塩水中に 2 週間浸漬した後の含水フィルム を試料とした。測定は室温空気中, チャック間隔 $2 \mathrm{~cm}$, 引張速度 $50 \mathrm{~cm} / \mathrm{min}$ で行った。 な抢，含水フィルムについては式(1)により 含水率を求めた.

Water content $(\%)=\frac{(\text { wt of wet film })-(\text { wt of dry film })}{(\text { wt of dry film })}$

$$
\times 100
$$

$2 \cdot 7$ セグメント化ポリウレタンウレアの動的力学的試験 厚さ約 $350 \mu \mathrm{m}$, 幅 $1 \mathrm{~cm}$, 長さ $4 \mathrm{~cm}$ のフィルムを試料として,レ スカ(侏製自由減衰型動的粘弾性装置 RD1100AD を用いて動的力 学的試験を行った.

Table I. Synthesis ${ }^{\mathrm{a}}$ of segmented polyurethaneureas.

\begin{tabular}{|c|c|c|c|c|c|c|c|c|c|c|c|}
\hline \multirow{2}{*}{$\begin{array}{l}\text { Sample } \\
\text { code }\end{array}$} & \multicolumn{3}{|c|}{ Prepolymer } & \multirow{2}{*}{$\frac{[\mathrm{DBUe}]}{[\mathrm{OH}]}$} & \multicolumn{3}{|c|}{$\begin{array}{l}\text { Reaction of } \\
\text { prepolymer and MDI }\end{array}$} & \multicolumn{3}{|c|}{$\begin{array}{l}\text { Chain-extension } \\
\text { reaction }\end{array}$} & \multirow{2}{*}{$\begin{array}{l}\text { Yield }^{f} \\
(\%)\end{array}$} \\
\hline & $M_{\mathrm{n}}^{\mathrm{b}}$ & $M_{\mathrm{w}} / M_{\mathrm{n}}^{\mathrm{c}}$ & $\begin{array}{c}\mathrm{EU} \\
\text { content }^{\mathrm{d}} \\
(\mathrm{mol} \%)\end{array}$ & & $\begin{array}{l}\text { Conc. of the } \\
\text { solution }(\%)\end{array}$ & $\begin{array}{l}\text { Temp. } \\
\left({ }^{\circ} \mathrm{C}\right)\end{array}$ & $\begin{array}{l}\text { Time } \\
(h)\end{array}$ & $\begin{array}{l}\text { Conc. of the } \\
\text { solution }(\%)\end{array}$ & $\begin{array}{l}\text { Temp. } \\
\left({ }^{\circ} \mathrm{C}\right)\end{array}$ & $\begin{array}{l}\text { Time } \\
(\mathrm{h})\end{array}$ & \\
\hline SPUU-2 & 1830 & 1.5 & 0 & 3 & 15 & 30 & 1.5 & 4.1 & $\begin{array}{c}30 \\
30-50\end{array}$ & $\begin{array}{l}1.5 \\
0.5\end{array}$ & 82 \\
\hline SEUU-3 & 2430 & 1.5 & 33 & 3 & 18 & 30 & 1.5 & 5.1 & $\begin{array}{c}30 \\
30-50\end{array}$ & $\begin{array}{l}0.4 \\
0.5\end{array}$ & 83 \\
\hline SEUU-6 & 4040 & 1.3 & 62 & 3 & 22 & 30 & 1.5 & 6.6 & $\begin{array}{c}30 \\
30-50\end{array}$ & $\begin{array}{l}1.0 \\
0.5\end{array}$ & 78 \\
\hline
\end{tabular}

a Synthesized by the prepolymer method. b Measured by vapor pressure osmometer.

c Measured by gel permeation chromatography. a Measured by ${ }^{1} \mathrm{H}-\mathrm{NMR}$.

e 1,8-Diazabicyclo[5.4.0] undecene-7 as a catalyst. f Yield after the soxhlet's extraction. 
Table II. Properties of segmented polyurethaneureas.

\begin{tabular}{|c|c|c|c|c|c|}
\hline \multirow{2}{*}{$\begin{array}{l}\text { Sample } \\
\text { code }\end{array}$} & \multirow{2}{*}{$\begin{array}{c}\text { Antithrombogenicity } \\
\text { CTI }^{\mathrm{a}}\end{array}$} & \multicolumn{3}{|c|}{ DSC } & \multirow{2}{*}{$\begin{array}{c}\text { SAXS } \\
\frac{\mathrm{d}^{\mathrm{e}}}{(\AA)} \\
(\AA)\end{array}$} \\
\hline & & $\begin{array}{l}T_{\mathrm{g}, \mathrm{s}}{ }^{\mathrm{b}} \\
(\stackrel{\circ}{\mathrm{C}})\end{array}$ & $\begin{array}{l}T_{\mathrm{m}, \mathrm{s}} \mathrm{c} \\
\left({ }^{\circ} \mathrm{C}\right)\end{array}$ & $\begin{array}{c}T_{\mathrm{m}, \mathrm{h}}{ }^{\mathrm{d}} \\
\left({ }^{\circ} \mathrm{C}\right)\end{array}$ & \\
\hline SPUU-2 & 3.6 & -73.2 & -4.2 & 272.3 & 113 \\
\hline SEUU-3 & 4.9 & -75.8 & 1.7 & 280.6 & 121 \\
\hline SEUU-6 & 4.3 & -80.1 & 7.5 & 280.7 & 112 \\
\hline
\end{tabular}

a Coagulation time index measured by the Lee-White method.

b Glass transition temperature of soft segment.

${ }^{c}$ Melting point of soft segment.

d Melting point of hard segment domain.

e Bragg spacing calculated from $d=2 \pi / q, q$ : scattering vector.

\section{3. 結 果}

$3 \cdot 1$ セグメント化ポリウレタンウレアの合成

SEUU およびSPUU の合成条件と結果を Table I に示す。い ずれのポりマーも反応点濃度を一定にして合成した。ゲル化する ことなく反応は進行し、ソックスレー抽出後の収率も高い.

\section{$3 \cdot 2$ セグメント化ポリウレタンウレアの抗血栓性}

Table II に Lee-White 法凝血試験の結果を示した. CTI 值よ り明らかなように，分子量1830の HT-PTをプレポリマーとする SPUU-2 より，親水性の PEO セグメントを導入した SEUU-3, SEUU-6 の抗血栓性は優れている. しかし，EO 含量か $52 \mathrm{~mol} \%$ のSEUU-6 の抗血栓性は SEUU-3 そ劣り, EO 含量には最適值 が存在すると思われる。

\section{$3 \cdot 3$ セグメント化ポリウレタンウレアの DSC 分析}

キャスト法で作製したフィルムの DSC 測定の結果を Table II に示す。 いずれのフィルムもソフトセグメントのガラス転移温度 $\left(T_{\mathrm{g}, \mathrm{s}}\right)$ と融点 $\left(T_{\mathrm{m}, \mathrm{s}}\right)$, 执よびハ・・゙セグメントの融点 $\left(T_{\mathrm{m}, \mathrm{h}}\right)$ が観測され，ミクロ相分離構造を有していることが明らかとなっ た. $\mathrm{EO}$ 含量が大きくなるにつれて， $T_{\mathrm{g}, \mathrm{s}}$ は低温側へシフトし，

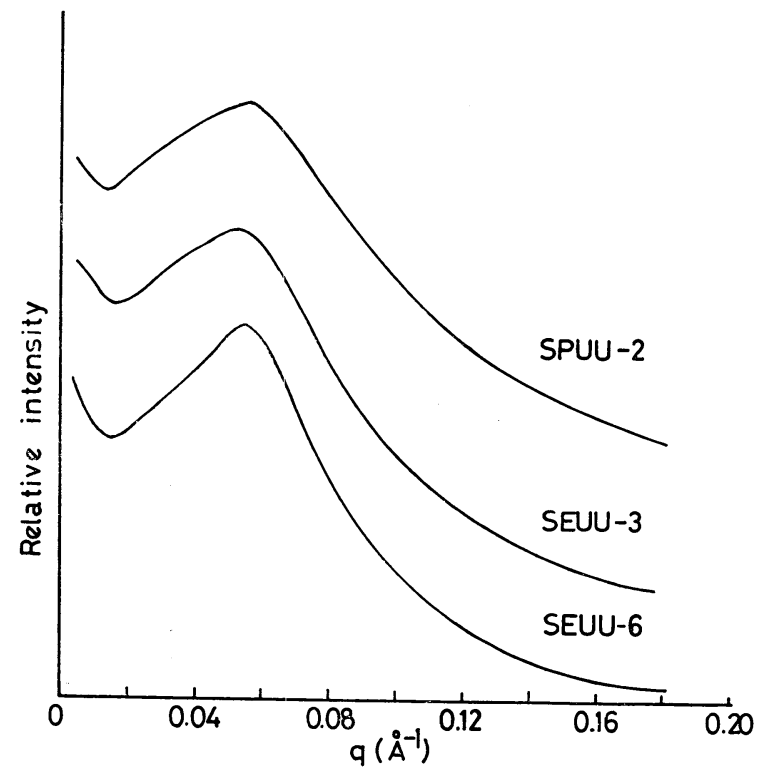

Fig. 2 SAXS curves of segmented polyurethaneureas.

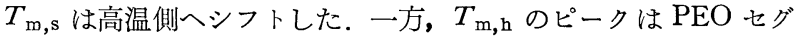
メントの導入により高温側ヘシフトした。

\section{$3 \cdot 4$ セグメント化ポリウレタンウレアの SAXS 分析}

Fig. 2 飞AXS 曲線を示した。縦軸は相対散乱強度で, 横軸 は散乱ベクトル $(q)$ である. 散乱ベクトルを定義する式(2)と Bragg の式（式(3)）より式(4)が導かれ，Bragg spacing (d) を求 めた。

$$
\begin{aligned}
& q=4 \pi \sin \theta / \lambda \\
& 2 d \sin \theta=n \lambda \\
& d=2 \pi / q
\end{aligned}
$$

ここで, $q$ : 散乱ベクトル, $\theta$ : 入射 $\mathrm{X}$ 線と格子面とのなす角 度, $n$ : 反射の次数, $\lambda: \mathrm{CuK}_{\alpha}$ 線の波長, $d:$ Bragg spacing で ある。いずれのポリマーも明確に散乱極大を示し，ミクロ相分離 構造の存在を確認することができた. Table II には式(4)から計算 した Bragg spacing を示す。 いずれの Bragg spacing も100Åの オーダーであり, EO 含量 $33 \mathrm{~mol} \%$ SEUU-3 でこの值は最も 大さい，

$3 \cdot 5$ セグメント化ポリウレタンウレアの引張特性

Fig. 3 Kセグメント化ポリウレタンウレアの乾燥フィルムと,

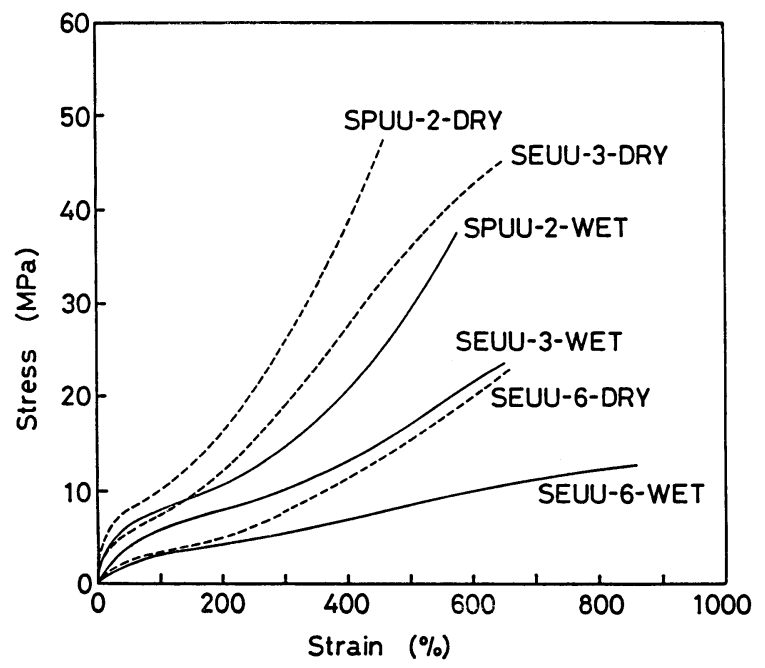

Fig. 3 Stress-strain curves of segmented polyurethaneureas. ---- : dry samples, — : wet samples which were soaked in normal saline solution for 2 weeks at $37^{\circ} \mathrm{C}$. 
Table III. Tensile properties ${ }^{a}$ of segmented polyurethaneureas.

\begin{tabular}{|c|c|c|c|c|c|c|c|c|c|c|c|c|c|c|c|}
\hline \multirow[b]{2}{*}{$\begin{array}{l}\text { Sample } \\
\text { code }\end{array}$} & \multicolumn{7}{|c|}{ Dry sample } & \multicolumn{8}{|c|}{ Wet sample } \\
\hline & $\begin{array}{c}\mathrm{M}_{5 n} \\
(\mathrm{MPa})\end{array}$ & $\begin{array}{c}\mathrm{M}_{300} \\
(\mathrm{MPa})\end{array}$ & $\begin{array}{c}T_{\mathrm{B}} \\
(\mathrm{MPa})\end{array}$ & $\begin{array}{l}E_{\mathrm{B}} \\
(\%)\end{array}$ & $\begin{array}{c}C_{1} \mathrm{~b} \\
(\mathrm{MPa})\end{array}$ & $\begin{array}{c}C_{2}{ }^{\mathrm{b}} \\
(\mathrm{MPa})\end{array}$ & $\underset{\left(10^{-4} \mathrm{~mol}^{\nu^{\mathrm{c}}}\right.}{\left.\mathrm{cm}^{3}\right)}$ & $\begin{array}{l}\text { Water } \\
\text { content } \\
(\%)\end{array}$ & $\begin{array}{c}\mathrm{M}_{50} \\
(\mathrm{MPa})\end{array}$ & $\begin{array}{c}\mathrm{M}_{300} \\
(\mathrm{MPa})\end{array}$ & $\begin{array}{c}T_{\mathrm{B}} \\
(\mathrm{MPa})\end{array}$ & $\begin{array}{c}E_{\mathrm{B}} \\
(\%)\end{array}$ & $\begin{array}{c}C_{1}^{\mathrm{b}} \\
(\mathrm{MPa})\end{array}$ & $\begin{array}{c}C_{2}{ }^{\mathrm{b}} \\
(\mathrm{MPa})\end{array}$ & $\left.\begin{array}{c}\nu^{\mathrm{c}} \\
\left(10^{-4} \mathrm{~mol} /\right. \\
\mathrm{cm}^{3}\end{array}\right)$ \\
\hline SPUU-2 & 8.1 & 25.1 & 47.4 & 475 & 0.31 & 5.4 & 2.6 & 4.9 & 6.3 & 14.7 & 37.5 & 580 & 0.38 & 3.5 & 3.1 \\
\hline SEUU-3 & 5.9 & 18.8 & 45.0 & 650 & 0.51 & 3.1 & 4.3 & 7.4 & 4.0 & 11.2 & 23.6 & 650 & 0.63 & 2.1 & 5.1 \\
\hline SEUU-6 & 2.4 & 7.7 & 22.8 & 660 & 0.41 & 1.0 & 3.4 & 46.5 & 2.3 & 5.4 & 12.6 & 830 & 0.43 & 0.94 & 3.5 \\
\hline
\end{tabular}

a Extention speed : $50 \mathrm{~mm} / \mathrm{min}$ at room temperature.

b $\sigma=2\left(C_{1}+\left(C_{2} / \alpha\right)\right)\left(\alpha-1 / \alpha^{2}\right)$ (Mooney-Rivlin equation).

c Calculated from $2 C_{1}=\nu k T$.

a Soaked in normal saline solution at $37^{\circ} \mathrm{C}$ for 2 weeks.

e Water content $(\%)=\{$ (wt of wet sample) - (wt of dry sample) $\} /$ (wt of dry sample) $\times 100$.

含水フィルムの引張試験に招ける応力ーひずみ曲線を示す。をた， Table III には50\%伸長時のモジュラス $\left(\mathrm{M}_{50}\right)$, 300\%伸長時のモ ジュラス $\left(\mathrm{M}_{300}\right)$, 引張強さ $\left(T_{\mathrm{B}}\right)$, 伸び $\left(E_{\mathrm{B}}\right)$ の值を示した。 い ずれのポリマーフィルムも, 低モジュラスと大きな伸びに特徴付 けられる生体軟組織と同様な特性を有し，エラストマーとしての 強度も大きい。乾燥フィルムに执いても含水フィルムに执いても $\mathrm{PEO}$ セグメントを導入したSEUUは, SPUU より高ひずみにお けるモジュラスは小さく, 伸びは大きい. SEUU-3の乾燥フィル ムはSPUU-2に匹敵する引張強さを示したが，含水状態では EO 含量が多くなるにつれて引張強さが小さくなる傾向が認められた．

\section{$3 \cdot 6$ セグメント化ポリウレタンゥレアの動的力学的性質}

SPUU と SEUU の複素剪断弾性率 $(G)$ と動的損失 $(\pi \tan \delta)$ の温度分散を Fig. 4 に示し, Table IV には Fig. 4 から求め た転移温度と $37^{\circ} \mathrm{C}$ に打ける $G$ 值を示した. SPUU-2ではー $65^{\circ} \mathrm{C}$,

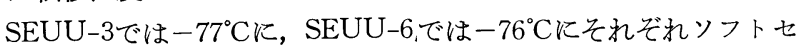
グメントのミクロブラウン運動に起因する $\alpha_{\mathrm{a}}$ 吸収が観測された. SPUU-2では冷却時に生じたソフトセグメント結晶相の融解に起 因する $\alpha_{\mathrm{f}}$ 吸収は不明瞭であるが, SEUU-3 と SEUU-6ではそれ ぞれ $-15^{\circ} \mathrm{C},-40^{\circ} \mathrm{C}$ 明瞭な $\alpha_{\mathrm{f}}$ 吸収が認められた。また， $G$ 值 の温度分散の結果から, いずれのポリマーもゴム状領域を示した 後, 約 $220^{\circ} \mathrm{C}$ 付近でハードセグメントドメインの軟化が起こり,
Table IV. Results of the dynamic mechanical test.

\begin{tabular}{ccccc}
\hline \multirow{2}{*}{$\begin{array}{c}\text { Sample } \\
\text { code }\end{array}$} & \multicolumn{3}{c}{ Transition temperature $\left({ }^{\circ} \mathrm{C}\right)$} & \multirow{2}{*}{$\begin{array}{c}G^{\mathrm{d}} \text { at } 37^{\circ} \mathrm{C} \\
(\mathrm{MPa})\end{array}$} \\
\cline { 2 - 4 } & $\alpha_{\mathrm{a}^{\mathrm{a}}}$ & $\alpha_{\mathrm{f}}{ }^{\mathrm{b}}$ & $\alpha_{\mathrm{s}-\mathrm{h}}{ }^{\mathrm{c}}$ & \\
\hline SPUU-2 & -65 & $-\mathrm{-}^{\mathrm{e}}$ & 115 & 1.10 \\
SEUU-3 & -77 & -15 & $-{ }^{\mathrm{e}}$ & 0.23 \\
SEUU-6 & -76 & -40 & $-\mathbf{-}^{\mathrm{e}}$ & 0.09 \\
\hline
\end{tabular}

a Corresponding to glass transition of soft segment.

b Corresponding to melting of soft segment.

c Damping peak due to destruction of the interaction between soft and hard segment.

d Shear modulus.

e Not detected.

$G$ 值は急激に低下した. 以上の結果はDSC測定の結果と一致して, これらのセグメント化ポリウレタンウレアがミクロ相分離構造を 有していることを示す。これらの結果は高原らの PTHF ベース のセグメント化ポリウレタンウレアの研究 ${ }^{12)}$ と一致した.

SPUU-2 で認められる $30^{\circ} \mathrm{C}$ 付近から $150^{\circ} \mathrm{C}$ 付近の吸収ピークは, 恐らくポリェーテル酸素とハードセグメントの $\mathrm{NH}$ 基との間の水 素結合の切断 $\left.{ }^{13}\right)$ に起因する吸収ピーク $\left(\alpha_{\mathrm{s}-\mathrm{h}}\right)$ であると考㝋られ

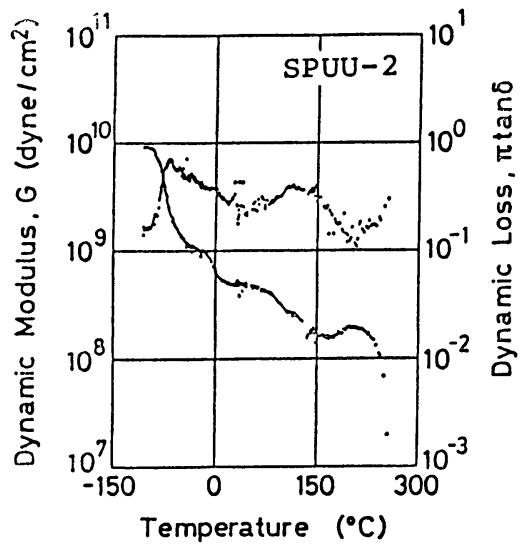

(a)

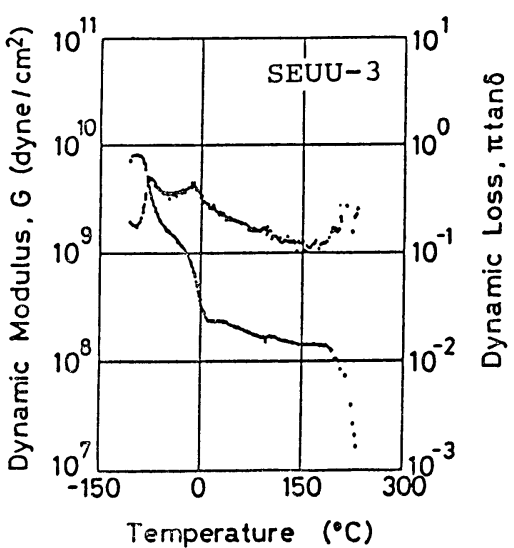

(b)

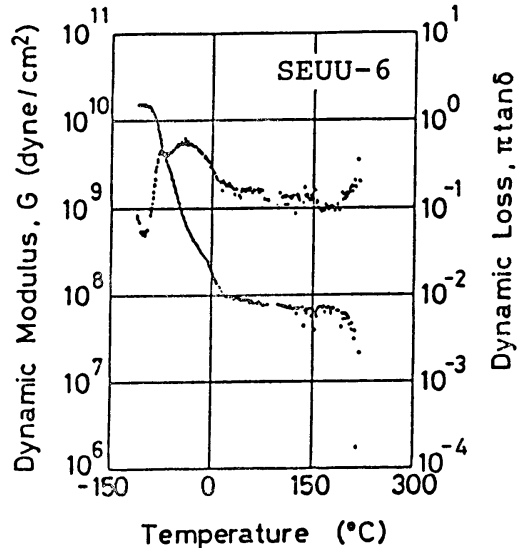

(c)

Fig. 4 Dynamic modulus $(G)$ and dynamic loss $(\pi \tan \delta)$ curves of segmented polyurethaneureas, (a) : SPUU-2, (b) : SEUU-3, (c) : SEUU-6, 
る。すなわち, SPUU-2ではハードセグメントとソフトセグメン トの相分離がSEUUほど良好に進行していないと推定できる。

\section{4. 考察}

$4 \cdot 1$ セグメント化ポリウレタンウレアのミクロ相分離構造 DSC 和よび動的力学的試験の結果から, PTHF の両末端にPE $\mathrm{O}$ セグメントを導入した PEO-PTHF-PEOトリブロックコポリ エーテルをポリウレタンウレアのソフトセグメントに用いること により，ソフトセグメントとハードセグメントを良好に相分離さ せることが可能であった。これはポリエーテルの表面自由エネル ギーの大きさが， $\mathrm{PTHF} \approx \mathrm{PPO}<$ ハードセグメント $<\mathrm{PEO}$ の順 に増加すること ${ }^{14), 15)}$ から推定すると, PTHF とハードセグメン トの間に導入された親水性 PEO セグメントの影響によって，よ りハードセグメントの㠜集が促進されたものであると考觉られ る ${ }^{16)}$. Fig. 4 に示した $G$ 值のゴム領域から明らかなように, EO 含量 $33 \mathrm{~mol} \%$ の SEUU-3 は $62 \mathrm{~mol} \%$ SEUU-6 と比較して, わずかではあるがその相分離の程度は良い. SEUU-6はソフト七 グメントの分子量が大きく (4040)，かえってそれが相分離に不 利に働いたと考兄られる.すなわち，ソフトセグメント鎖長には 良好なミクロ相分離を形成するための最適值が存在することを示 唆している.

SAXS 測定では，Table II に示すように SEUU-3 の Bragg spacing の值が最も大きい。これは SEUU-3のセグメントドメイ ン間の距離が大きいこと，つまりSEUU-3ではハードセグメント の凝集が最も進んでいることを示寸と思われる，また，Fig. 2 に示した散乱曲線の形状を比較すると, SEUU-6が最もシャープ であり，SEUU-6のハードセグメントドメインのドメインサイズ の分布はSEUU-3より狭いと解釈できる。この点については今後 さらに検討を加える必要がある。

\section{$4 \cdot 2$ セグメント化ポリウレタンウレアのカ学的性質}

乾燥フィルムと $37^{\circ} \mathrm{C}$ 生理食塩水中に 2 週間浸漬した後の含水フ イルムの引張強さを比較すると, 含水によって SEUUフィルム は約 2 分の 1 の引張強さの低下を起こしている，PEO セグメン

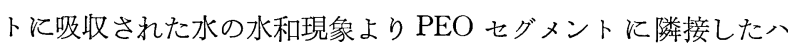
一ドセグメントドメインの高次構造が変化したと考えられる。乙 かし，SEUU-6 は含水率が46\%とかなりの水を含むが，引張強さ $12.6 \mathrm{MPa}$ ，伸び $830 \%$ という優れた力学的性質を示し，ハードセ グメントドメインの凝集が強固で水分の影響が少ないものと推定 される。 引き続き $37^{\circ} \mathrm{C}$ 生理食塩水中に 6 力月間浸漬した後も, 力 学的性質にほとんぞ変化は認められなかった ${ }^{8)}$.

ゴム弾性体の引張特性を記述する式として, Mooney-Rivlin式 17),18)が良く知られている。

Mooney-Rivlin式

$$
\sigma=2\left(C_{1}+\frac{C_{2}}{\alpha}\right)\left(\alpha-\frac{1}{\alpha^{2}}\right)
$$

ここで, $\sigma$ :引張応力, $\alpha$ : 伸長比, $C_{1}, C_{2}$ : 定数であり, $C_{1}$ は 次式で表される.

$$
2 C_{1}=\nu k T
$$

$\nu$ : 網目鎖濃度, $k$ : ボルツマン定数, $T$ : 絶対温度である. Mooney-Rivlin プロットの切片执よび勾配より $C_{1}, C_{2}$ が決定で きまた $C_{1}$ 項より式(6)を用いて力学的に測定された網目鎖濃度

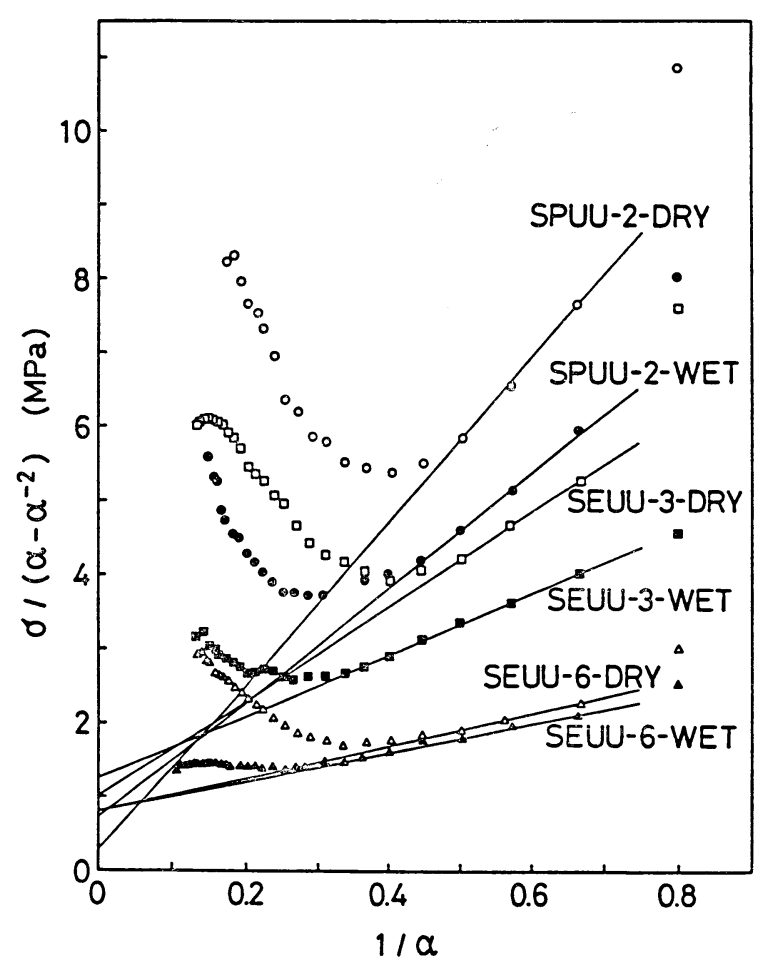

Fig. 5 The Mooney-Rivlin plots of segmented polyurethaneureas.

$\bigcirc, \square, \triangle$ : dry samples, $\bullet, \boldsymbol{\square}, \boldsymbol{\Delta}$ : wet samples which were soaked in normal saline solution for 2 weeks at $37^{\circ} \mathrm{C}$.

が計算される. これらの結果を Fig. 5, Table III に示した. $C_{1}$ 項より得られた見掛けの網目鎖濃度は $10^{-4} \mathrm{~mol} / \mathrm{cm}^{2}$ のオーダ 一の值となり，これは通常のジェン系ゴム架橋体と同程度であっ た。わずかではあるが，ミクロ相分離の良好な SEUU-3で最も 見掛けの網目鎖濃度が大であった。架橋点の働きをするリジッド なハードセグメントドメインの割合が多いと推定する。また，水 和現象によって $C_{1}$ 項が大きくなる傾向が見られた. 力学的に決定 された膨潤試料の網目鎖濃度は，乾燥試料の網目鎖濃度より小さ くなると考えられる．というのは乾燥固体試料では物理的なから み合い点が網目鎖濃度の増加に寄与して和り, 膨潤試料ではこの寄 与が小さくなっているからである.セグメント化ポリウレタンウレ アの場合, 熟成あるいは熱処理がミク口相分離構造, ひいては力学 的性質に影響する. 本実験ではフィルム浸漬を $37^{\circ} \mathrm{C}$ の生理食塩水中 で 2 週間行っているので，この間の熟成効果により相分離状態が変 化して網目鎖濃度に影響が生じた可能性がある。

$C_{2}$ は Fig. 6 に示すよ 5 に EO 含量の増加によって低下し，さ らに含水によっても減少する傾向が認められた， $C_{2}$ 項の意味につ いてはまだ明確でないが， $C_{2}$ はゴムの種類により変化すること， 加硫度にはあまり影響されないこと，膨潤により值は小さくなる こと，網目鎖濃度よりはむしろ網目構造に低存することなどが知 られている ${ }^{19)}$. Fig. 6 より明らかなようにこれらの試料の場合, $\mathrm{EO}$ 含量の増加に伴って極性が上るにつれ，またポリマー間の水 素結合の密度が減少するにつれて $C_{2}$ は低下していると言える。擬 架橋点となるハードセグメントドメインの影響だけでなく，ソフ トセグメントとハードセグメントの間の相互作用も $C_{2}$ 項汇影響し 


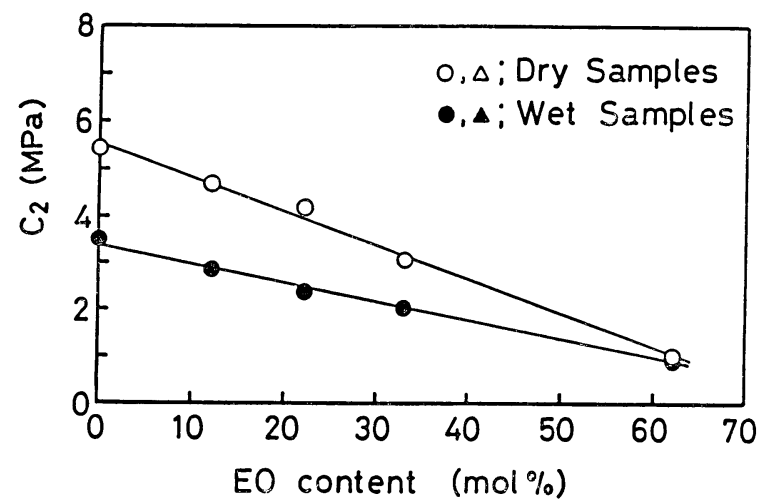

Fig. 6 Relationships between $C_{2}$ and $\mathrm{EO}$ content in segmented polyurethaneureas.

$\bigcirc$ : dry samples, : wet samples which were soaked in normal saline solution for 2 weeks at $37^{\circ} \mathrm{C}$.

ているものと思われる20).

Fig. 4 に示すように，複素剪断弾性率のゴム状領域はいずれ のポリウレタンウレアも $220^{\circ} \mathrm{C}$ 付近まで広がっている. しかし， SPUU-2は温度によってモジュラスの大きさが大きく異なってい る. Table IV に37Cに拈けるモジュラスを示した. PEO セグ メントは一方で可塑剤を添加したと同じくフィルムを柔軟にし， 他方でハードセグメントの㠜集を促進させて物理的架橋点をより 強固にし，ミクロ相分離構造を安定化したと考光られる.

SPUU-2のフィルムにいくつもの減衰ピークが現われたことは その損失が大きいことを意味し，長期の疲学寿命を考兵た場合，

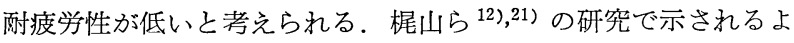
ろに, ミク口相分離の発達の程度は耐疲労性に最も大きく影響を 与えると考觉られる。

\section{$4 \cdot 3$ セグメント化ポリウレタンウレアの抗血栓性}

ミクロ相分離構造を有するポリマーの抗血栓性についてはいく つかの仮説や理論がある ${ }^{22)}$. SPUU や SEUU が示す良好な抗血 栓性もミクロ相分離構造に依存すると考兄られる。しかし, 詳細 に見るとさらにいくつかの因子を考虑に入れなければならない． SPUU に比べて SEUU の抗血栓性が向上したことは, ソフトセ グメントに PEO セグメントを導入したことによる親水性の増加 が一因と考えられる。すなわち，界面自由エネルギーが低下する ことによりたんぱく質が吸着し難く，かつ脱着しやすくなった ${ }^{23)}$ と考えられる。 また，SEUU-6に比べ SEUU-3の方が CTI 值が 大きいことから，ポリマー表面の親水一踈水性のバランスが抗血 栓性に影響したと考兄られる，さらに，ドメインの大きさや分布 などの因子も抗血栓性や力学的性質に影響しているにらがいない， これらの解明は今後の課題であろう。

\section{5. 結 諭}

PTHFの両末端にEOニニットを導入したPEO-PTHF-PEOト リブロックコポリエーテルより合成した SEUUは, PTHFをソ
フトセグメントとするSPUU と比較して優れた抗血栓性を有す ることが判明した，抗血栓性はミクロ相分離構造の影響だけでな く親水性などの影響を受け，そのモルホロジー効果により，EO 含量 $33 \mathrm{~mol} \%$ SEUU-3が最も優れた抗血栓性を示した。 また, プレポリマーへの PEO セグメントの導入はソフトセグメントと ハードセグメントのミクロ相分離を促進し, 強固なハードセグメ ントドメインを形成することが明らかとなった。これは引張物性 に影響を与兄，含水による著しい力学的性質の低下を防いだ.

\section{文献}

1) Boretos, J.W., and Pierce, W.S., Science, 158, 1481 (1967).

2) Ibid., J. Biomed. Mater. Res., 2, 121 (1968).

3）松田武久, 有合化, 42, 1010 (1984).

4）山下岩男, 高分子加工, 35, 158 (1986).

5）池田裕子, 粎谷信三, 日ゴム協誌，62, 357 (1989).

6) Mucha, M., Colloid Polym. Sci., 264, 859 (1986).

7）池田裕子, 粎谷信三, 山下晋三, 山本 襄, 林 和子, 山下岩男, 日化誌, 699 (1986).

8) Kohjiya, S., Ikeda, Y., and Yamashita, S.. "Polyurethanes in Biomedical Engineering II", Plank, H., et al. Eds., Elsevier, Amsterdam (1987), p. 183.

9) Ikeda, Y., Kohjiya, S., Yamashita, S., Fukumura, H., and Yoshikawa, S., Polymer Journal, 20, 273 (1988).

10）今井康二, 第15回医用高分子研究会講演要旨集, p. 29 (1982).

11) Hayashi, H., Hamada, F., Suehiro, S., Masaki, N., Ogawa, T., and Miyaji, H., J. Appl. Cryst., 21, 330 (1988).

12）高原 淳, 田下純一, 梶山千里, 高柳素夫, 高分子論文集, 39, 203 (1982).

13）木村逸郎, 石原英昭, “高分子物性と分子構造”, 化学増刊 58, 永沢 満, 山下雄也共編 (1973), 化学同人, p. 207.

14）松田武久, 阿久津哲造, Polymer Preprints, Jpn., 32(3), 474 (1983).

15）高原 淳, 梶山千里, 日化誌, 1293 (1985).

16）池田裕子, 粎谷信三, 山下晋三, 古谷哲朗, 柴山充弘, 野 村春治, 第31回高分子研究発表会, p. 6 (1985).

17) Mooney, M., J. Appl. Phys., 11, 582 (1940).

18) Rivlin, R.S., "Rheology, Vol. I”, Academic Press, N. Y. (1956).

19）岡本 弘，日ゴム協誌，48，623 (1975).

20）池田裕子, 竹迫祥一, 粎谷信三, 山下晋三, 山下岩男, 日 ゴム協誌，62，242（1989）。

21）梶山千里, 高原 淳, 日ゴム協誌, 59, 33 (1986).

22）松田武久, 化学工学, 50, 675 (1986).

23) Matsuda, T., and Akutsu, T., ACS Preprints (Polymer Materials Science and Technology), 48, 498 (1983). 